\title{
De Beneficentia: A Homily on Social Action attributed to Basil of Caesarea*
}

\author{
Susan R. Holman ${ }^{a}$, Caroline Macé ${ }^{\mathrm{b}}$ and Brian J. Matz ${ }^{\mathrm{c}, 1}$ \\ a) Harvard University \\ b) K.U. Leuven \\ c) Carroll College
}

\begin{abstract}
This paper introduces an anonymous work attributed to Basil of Caesarea entitled, De beneficentia, or "On beneficence." The text is known from one manuscript dating to the thirteenth or fourteenth century, Berlin, Deutsche Staatsbibliothek, Phillipps 1467 (gr. 63), a collection of genuine and pseudonymous Basilian homilies. Although pseudonymous and extant (as far as we can determine) only in this sole manuscript, in some quoted fragments from the ninth and twelfth centuries, and in a sixteenthcentury Latin translation, De beneficentia, shares a number of characteristics common to social homilies preached in the late fourth and early fifth centuries. This paper discusses the Berlin manuscript text in the context of the known fragments, other spurious, dubious, or pseudonymous homilies attributed to Basil, and its attributed relationship to social preaching in Christian late antiquity, and offers a new edition of the Greek text with its first English translation.
\end{abstract}

\footnotetext{
*) The authors would like to acknowledge and express gratitude for the felicitous teamwork that has made this work possible. The critical edition offered here is almost entirely the work of CM; the translation represents equal efforts by all co-authors, with BM and SRH judiciously crafting the English narrative as CM kept us faithful to nuance and grammar; BM drafted the section on social preaching in late antiquity, and BM and SRH collaborated extensively on resources related to its attribution to Basil of Caesarea. An earlier version of that section was presented at the 2009 Annual Meeting of the North American Patristics Society; we thank that audience for their comments. We would also like to thank our anonymous reviewer, who suggested very valuable corrections.

1) Susan R. Holman: PO Box 380252, Cambridge, MA 02238-0252, USA, Susan_Holman @harvard.edu. Caroline Macé: Katholieke Universiteit Leuven, O.E. Griekse Studies, Blijde Inkomststraat 21, bus 3318, B-3000 Leuven, BELGIUM, Caroline.Mace@arts.kuleuven.be.
} 


\section{Keywords}

(pseudo-)Basil of Caesarea, social ethics, early Christianity, Greek homiletic

\section{The Direct Tradition of the Text}

The Greek text of the homily, De beneficentia, or "On beneficence," is apparently preserved in only one Greek manuscript, the Berlin, Deutsche Staatsbibliothek, Phillipps 1467 (gr. 63) (b49 in BBU), f. 218v-219v (hereafter identified as Berlin gr. 63). ${ }^{2}$ The manuscript, written on paper ("bombycinus"), is dated from the 13 th or 14 th cent. ${ }^{3}$ Its 270 folio pages also contain other homilies by Basil of Caesarea or attributed to him. There is no evidence within the manuscript of where it was copied; also unknown is its location prior to it ending up in the College of Jesuits in Clermont, from where it was bought by Gerard Meerman in 1764. Sir Thomas Phillipps purchased the manuscript in $1824 .{ }^{4}$ Many of the manuscripts that belonged to the College of Clermont came from the collection of Guillaume Pellicier (1490-1567), a well known book collector who was

Brian J. Matz: Carroll College, 1601 N. Benton Ave., Helena, MT 59625, USA, BMatz@ carroll.edu.

2) For our initial identification of the Berlin manuscript, we depended on P. J. Fedwick, Bibliotheca Basiliana Universalis: a study of the manuscript tradition, translations and editions of the works of Basil of Caesarea [= BBU], Corpus Christianorum, vol. II.2 (Turnhout: Brepols, 1996), 1182, where it is identified as W. Studemund and L. Cohn, Codices ex bibliotheca Meermanniana Phillippici Graeci nunc Berolinenses (Berlin, 1890), 20-21: "Codex 1467 Phill. = 130 Meerm. = 95 Clar., bombycinus, cm. 25 x 16,5, saec. XIII-XIV, foliorum 270”. Cf. also CPG 2948: M. Geerard [and F. Glorie for vol. 5], Clavis Patrum Graecorum, 5 vol., Corpus Christianorum (Turnhout: Brepols, 1974-1987); M. Geerard and J. Noret, Supplementum, Corpus Christianorum (Turnhout: Brepols, 1998) [= CPG]. In identifying relevant fragments, we also consulted the data bank of Greek manuscripts, PINAKES (http://pinakes.irht.cnrs.fr/), available online from (and updated by) the «Section Grecque» of the I.R.H.T. in Paris, as a continuation of the Greek Index Project carried on by W. M. Hayes and R. E. Sinkewicz (Pontifical Institute of Mediaeval Studies, Toronto).

3) It should be noted that we were not able to consult the manuscript in situ, but only on a reproduction, and the description above relies on the catalogue. We are grateful to the Berlin Deutsche Staatsbibliothek for their kind assistance in supplying both paper and microfilm images of the necessary pages.

4) A. N. L. Munby, The catalogues of manuscripts and printed books of Sir Thomas Phillipps: their composition and distribution, Phillipps Studies 1 (Cambridge: Cambridge University Press, 1951), 19, and A. N. L. Munby, The formation of the Phillipps library up to the year 1840, Phillipps Studies 3 (Cambridge: Cambridge University Press, 1954), 25. 
ambassador of King François I in Venice. A. Cataldi Palau's research on this collection, however, does not identify Berlin gr. 63 as one of Pellicier's manuscripts. ${ }^{5}$

In addition to this codex unicus, the text is also known through quotations in Greek anthologies (from the ninth and twelfth centuries), as well as from a Latin translation in the sixteenth century.

\section{The Text Tradition: Indirect Witnesses}

\section{Greek Citations}

The most ancient witness to De beneficentia is a quotation of a few lines

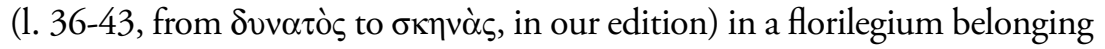
to the text known as Pseudo-Anastasius of Sinai's collection of Quaestiones et Responsiones (CPG 7746), PG 89, col. 465 A 12-B 7. While the authentic Quaestiones et Responsiones of Anastasius of Sinai (seventh century) have recently been edited, ${ }^{6}$ Pseudo-Anastasius's Quaestiones and the important anthology which accompanies them still await a critical edition. ${ }^{7}$ According to D. Sieswerda, this large collection originated in the second half of the ninth century, perhaps in Constantinople. ${ }^{8}$ In the florilegium follow-

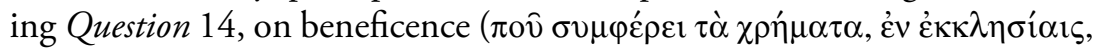

5) A. Cataldi Palau, "Les vicissitudes de la collection de manuscrits grecs de Guillaume Pellicier", Scriptorium 40 (1986), 32-53.

6) Anastasii Sinaitae Quaestiones et responsiones, ed. M. Richard ( $\dagger$ ) and J. Munitiz, Corpus Christianorum, Series Graeca 59 (Turnhout-Leuven: Brepols, 2006). Another recent study that includes Anastasius of Sinai (though not the Quaestiones) is Daniel F. Caner with Sebastian Brock, Richard M. Price, and Kevin van Bladel, History and Hagiography from the Late Antique Sinai, Translated Texts for Historians 53 (Liverpool: Liverpool University Press, 2010), esp. 173-199.

7) This edition is being prepared by M. De Groote (University of Ghent) and F. Thomson (University of Antwerp). The translation of this text in Old Slavonic is an important witness to the history of the text: see D. Tj. Sieswerda and F. J. Thomson, "A Critical Edition of Question 23 of the Pseudo-Anastasian 'Е $\omega \tau \alpha \pi$ окрí⿴\zh11\zh25 ceps of its Old Bulgarian Translation Associated with Tsar Symeon", in Philomathestatos. Studies in Greek Patristic and Byzantine Texts Presented to Jacques Noret for his Sixty-fifth Birthday, ed. by B. Janssens, B. Roosen and P. Van Deun, Orientalia Lovaniensia Analecta 137 (Leuven-Paris_Dudley, MA: Peeters Press, 2004), 567-589.

8) D. Tj. Sieswerda, Pseudo-Anastasius en Anastasius Sinaita, een vergelijking. De pseudoAnastasiaanse Quaestiones et Responsiones in de $\Sigma \Omega \mathrm{THPIO}$, prolegomena, tekst en commentaar (Amsterdam, 2004). 


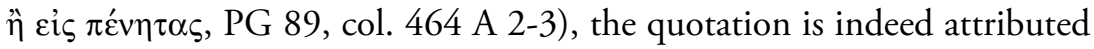

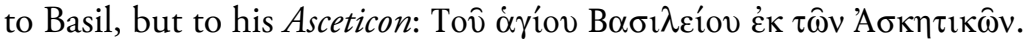

The difference between the text in Berlin gr. 63 and the quotation in the florilegium can perhaps best be demonstrated by comparing the two texts (the lines refer to our edition). This comparison is listed below, with the Greek that follows the bracket closure indicating the reading as found in Ps.-Anastasius:

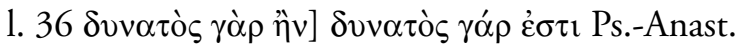

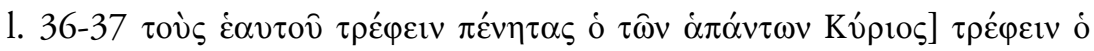

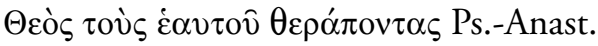

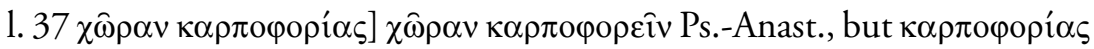
is indicated as a variant in a footnote

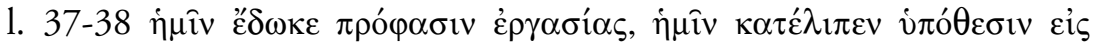

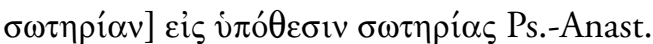

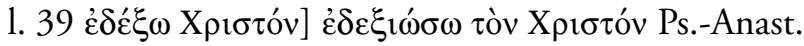

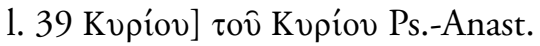

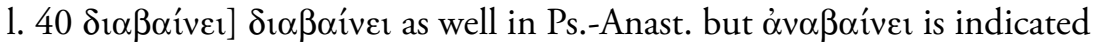
as a variant in a footnote

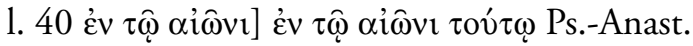

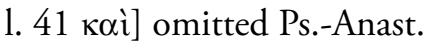

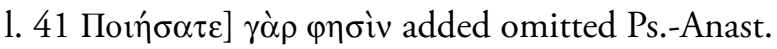

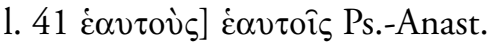

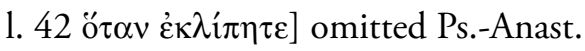

The quotation by pseudo-Anastasius is a precious testimony, since it is older than Berlin gr. 63 and might preserve some original readings. However, we did not use this quotation to establish our critical text since it is impossible to determine what comes from the original source and what was reworked by whoever compiled the citations.

The quotation does not end here in Ps.-Anastasius, but continues as fol-

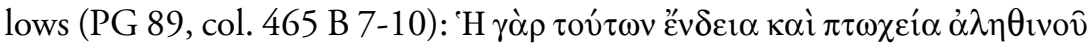

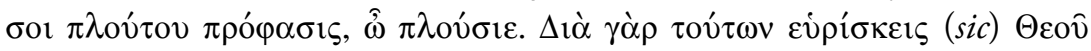

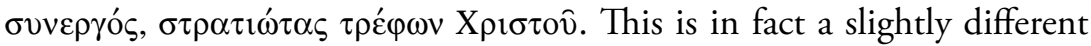
version of Pseudo-Basilius, Homilia de misericordia et judicio (CPG 2929; BBU, vol. II.2, 1189-1190), PG 31, col. 1713 A 7-11. The quotation in the florilegium ends with a sentence taken from the New Testament (Mat- 


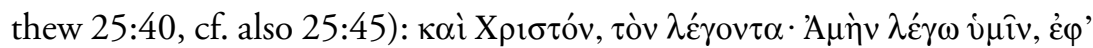

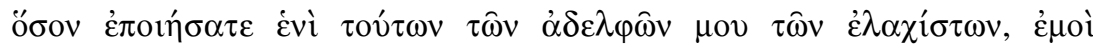
غ̇лoı́ $\sigma \alpha \tau \varepsilon$. Interestingly, according to the TLG, Basil used this quotation only in his ascetical works. ${ }^{9}$

The same quotation of De beneficentia can be found as well in Michael

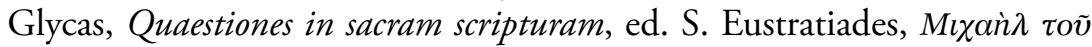

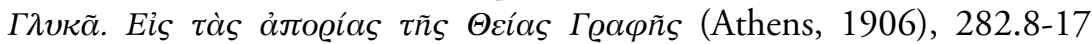
(ch. 26). A shorter extract of the same text (from 'E $\delta \varepsilon \xi 1 \omega \sigma \omega \omega$ to $\delta \varepsilon \dot{\varepsilon} \xi \omega \nu \tau \alpha$, 1. 58-63 in our edition) is quoted three times in the Vita sancti Cyrilli Phileotae. ${ }^{10}$ Those two quotations are probably based on Pseudo-Anastasius, since they share the same readings.

\section{The Sixteenth-century Latin Translation}

During the mid-sixteenth century, a Latin translation of only nine of the 48 homilies contained in Berlin gr. 63, including De beneficentia, was prepared by Francisco de Vergara (d. 1577). Vergara was professor of Greek letters and one-time rector at the Universidad de Alcalá (today the Universidad Complutense de Madrid) in Spain. Though the details of his biography are somewhat fragmentary, one scholar refers to him and his elder brother, Juan de Vergara, as conversos, meaning they were converts to Christianity, possibly from Judaism. ${ }^{11}$ Archbishop Cisneros of Toledo hired Juan as his secretary and gave him the responsibility to direct the establishment of humanist-based theological studies at Alcalá. ${ }^{12}$ Presumably, Juan was instrumental in his brother's appointment at the relatively new university. Francisco de Vergara's son, Francisco de Vergara the Younger, was apparently an artist; his sculpted silver statue of Ignatius Loyola still stands in the basilica at Loyola. ${ }^{13}$

9) Asceticon magnum (CPG 2875), PG 31, col. 917.24-26, 1001.12-14, 1025.13-15, 1188.6-7, 1281.38-40; Regulae morales (CPG 2877), PG 31, col. 772.32-34.

10) Nicolaus Catascepenus and E. Sargologos La Vie de Saint Cyrille le Philéote moine byzantin (+1110), Subsidia hagiographica 39 (Bruxelles: Société des Bollandistes, 1964), ch. 11, $\$ 1.16-20$; ch. $24, \$ 8.14-18$; and ch. 47, $\$ 10.1-5$.

11) Joseph Pérez and Janet Lloyd (transl.), The Spanish Inquisition: A History (New Haven, CT: Yale University Press, 2006), 105-106.

12) For information about Vergara, see Daniel A. Crews, Twilight of the Renaissance: The Life of Juan De Valdes (Toronto: University of Toronto Press, 2008), 33; idem, "Intellectual Sources of Spanish Imperialism: The Education of Juan de Valdes," Proteus 9 (1992), 38-42, here 40 .

13) Michael A. Mullett, The Catholic Reformation (London: Routledge, 1999), 202. 
Vergara published his Latin translation of nine homilies attributed to Basil in 1544. ${ }^{14}$ In his preface, he describes his source as simply an "old Greek codex with many of St. Basil's homilies written on velum" (veteri codice greco multarum D. Basilii homiliarum in membranis scriptarum). He also notes that the manuscript was placed at his disposal by a certain Ferdinand, who had some connection to royalty. Vergara includes in a final appendix a chart that identifies the Latin equivalent of the Greek symbols and abbreviations he found in the manuscript. These Greek symbols and abbreviations also correspond to those found in the Phillipps manuscript, but are not reliable "proof" of Vergara's source since such symbols and abbreviations were common for manuscripts produced at the same time.

A comparison of the contents of Berlin gr. 63 with Vergara's Latin translation easily leads one to conclude, as Fedwick certainly did, that "the source could not be other than" this our sole extant manuscript. ${ }^{15}$ Most notably, all nine of Vergara's texts are those now classed among Basil's spuria, and for which Vergara's Latin translation is the editio princeps: (1) De instituto Vivendi secundum Christum ( = De conversatione in Christo) $(\mathrm{CPG}$ 2945, Berlin gr. 63 fol. 218r-v); (2) De vita humana (CPG 5834, Berlin gr. 63 fol. 212-214v); (3) De temperantia (CPG 2946, Berlin gr. 63 fol. 209v-212); (4) De tolerantia et laboribus remedia conferentibus (CPG 2947, Berlin gr. 63 fol. 214v-218); (5) De beneficentia (Berlin gr. 63 fol. 218v-219v); (6) De misericordia et iudicio (CPG 2929, Berlin gr. 63 fol. 219v-222); (7) De jejunio quae duabus editis accedit tertia (= De jejunio 3, CPG 2928, Berlin gr. 63 fol. 171v-172v); (8) In laudem Meletii (CPG 3180, BHG 1243, Berlin gr. 63 fol. 254-258v); and (9) De virginitate (CPG 2081, Berlin gr. 63 fol. 222-228). In fact, there are only two texts among Basil's spuria which are to be found in Berlin gr. 63 that Vergara failed to include in his Latin translation: De spiritu sancto 2 (BHG 1934n,

14) Francisci Vergarae, D. Basilii Magni conciones novem antehac nusque excusae, nunc primum prodeunt in latinum sermonem translatae (Complutensis: Apud Iohannem Brocarium, 1544). One other work by Vergara known to us is De omnibus graecae linguae grammaticae partibus, libri quinque, in suum et verum ordinem restituti (Paris: Guillaume Morel, 1550). Included within this same book are also three collections of "miscellaneous notes". Vergara also had published an edition and translation of some treatises by Gregory of Nyssa in 1524, though the publication is no longer extant. Cf. D. J. Geanakoplos, Constantinople and the West: Essays on the Late Byzantine (Palaeologan) and Italian Renaissances and the Byzantine and Roman Churches. (Madison, WI: University of Wisconsin Press, 1989), 286 n. 20 .

15) BBU II.2, 857 n. 73. 
Berlin gr. 63 fol. 115v-121) and In Barlaam martyrem (CPG 2861, BHG 223, Berlin gr. 63 fol. 245v-248).

Despite these similarities of contents (but not sequence) between Berlin gr. 63 and Vergara's translation, and the agreement between his list of abbreviations and that found in the extant Greek manuscript, there is at least one reason for uncertainty that Berlin gr. 63 was the manuscript Vergara actually used for his translation. Unlike Vergara's description of his source manuscript as an "old" codex written on vellum (in membranis), Berlin gr. 63 was written, as noted above, on paper (bombycinus).

Since Vergara's translation style was to be as faithful as possible to the Greek, however, it is clear that the Greek text Vergara translated is identical to that of Berlin gr. 63. ${ }^{16}$ If Berlin gr. 63 is not the exemplar Vergara used for his translation, then his source must have been a direct ancestor, a text that perhaps disappeared in the fire that destroyed so many manuscripts at El Escorial in 1671. While this hypothesis cannot be proven and is not essential, it would explain the discrepancy between Vergara's description of a vellum source and the obvious paper material on which Berlin gr. 63 is written.

\section{Text and Translation}

The critical edition offered below is based wholly on the Berlin manuscript. As can be seen from our critical apparatus, the Greek text as it comes down to us contains several obvious corrections, though we could not determine whether those corrections were made by a second hand or by the copyist himself. We made no changes to the Greek text unless it was absolutely necessary, which was rarely the case. We also respected the copyist's orthography and accents except in a very few cases, all indicated in the apparatus.

\footnotetext{
16) Compare, for example, 1. 50-53 of our edition (precisely amongst the lines quoted by Ps.-Anastasius) with the Latin translation: "Potuit enim sine nobis pauperes suos alere, qui universorum est dominus; ceterum nobis locum dedit fructificandi, nobis obtulit occasionem quaestus, nobis reliquit materiam ad salutem."
} 


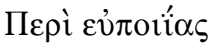

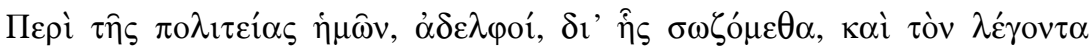

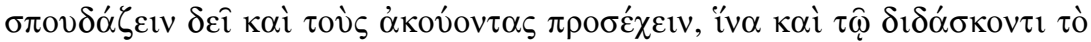

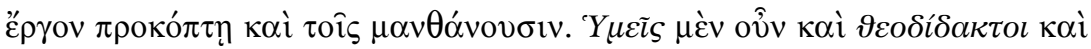

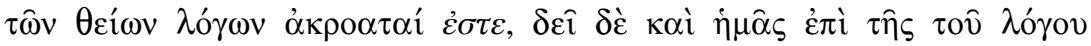

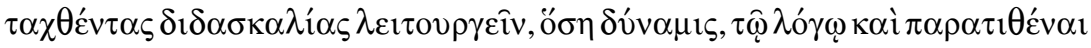

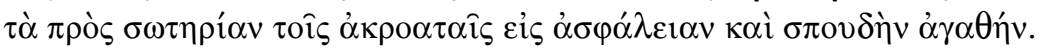

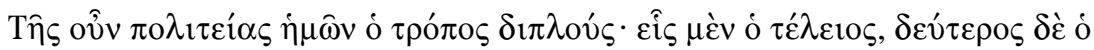

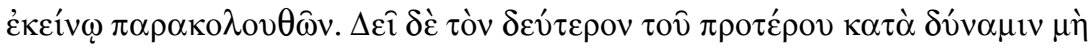

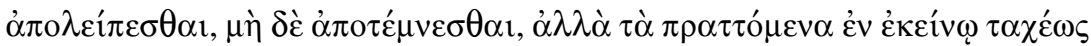

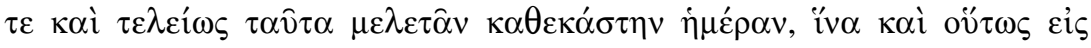
$\tau \varepsilon \lambda \varepsilon \iota^{\prime} \tau \eta \alpha \varphi \theta \dot{\alpha} \sigma \eta \tau \varepsilon \pi \mathrm{o} \tau \varepsilon^{\prime}$.

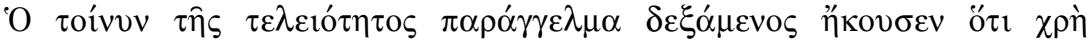

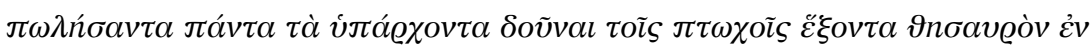

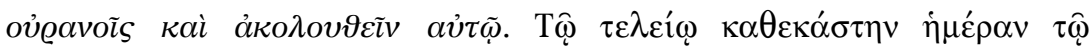

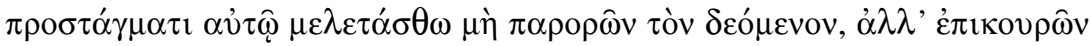

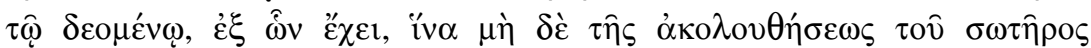

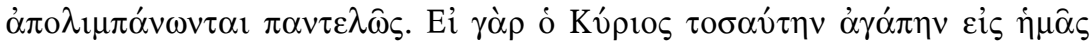

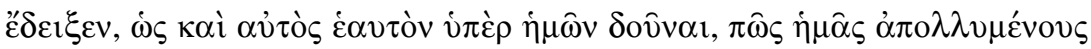

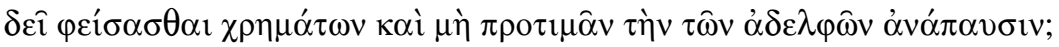

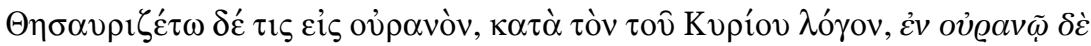

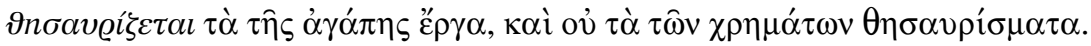

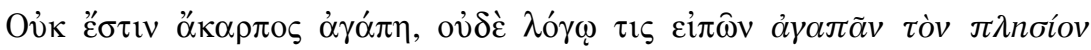

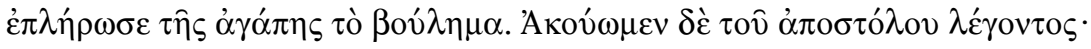

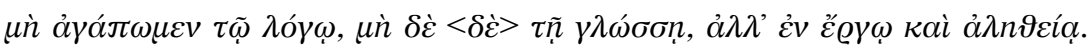

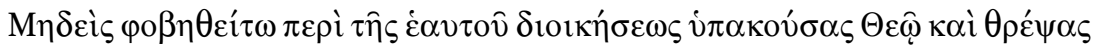

4-5 cf. I Thess. 4.9 14-15 = Matth. 19.21, Luc. 18.22, Marc. 10.21 21-22 cf. Matth. 6.20 (Luc. 12.33) 23 cf. Matth. 5.43 etc. $\mathbf{2 5}=$ I Ioh. 3.18

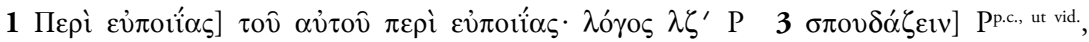

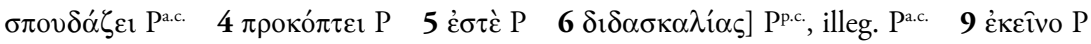

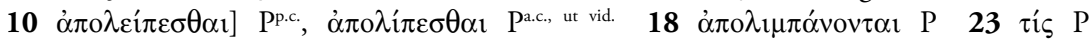
$\left.25 \delta \dot{\varepsilon}^{2}\right]$ deleuimus 


\section{On Beneficence}

Concerning our way of life, brethren, through which we are being saved, it is necessary that both the one who is speaking do his best, and that those who are listening pay attention, in order that the work advances both for the teacher and for the students. You, then, are disciples of God and hearers of the divine words, and we, who have been ordained to the teaching of the Word, we must serve the Word as much as we can and expound what is salutary for the audience with confidence and zeal for the good.

There are two manners in which to follow our way of life; the one is perfect, the second follows its example. The second, as far as it is possible, should not stay behind nor be cut off from the first, but you should practice daily everything which is done in this second manner of life, in a smooth and perfect way, so that in this way as well you may attain someday to perfection.

Therefore, he who has received the command of perfection has heard that "he [i.e., the rich man] must give all his possessions, after having sold them, to the poor and follow him [i.e., Christ], in order to have treasure in heaven." He should train himself daily in the perfect commandment itself-not neglecting the one in need but assisting the needy one from his possessions lest they fail utterly to obey the Savior. For if the Lord showed so much love to us so as to give even himself for us, how could we have [any] consideration for money to our damage, and not put above all considerations the tranquility of our brethren?

Let anyone store up goods for heaven according to the word of the Lord: in heaven, the works of love are stored up and not the treasures of money. Love is not unfruitful, nor did one who pretends to love his neighbor in word fulfill love's purpose. Let us listen to the apostle's saying, "Let us not love in word nor in speech, but in deed and truth." Let no one worry about his stewardship when he has obeyed God and supported his brother, for 


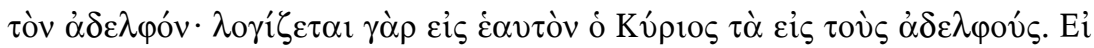

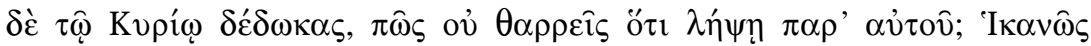

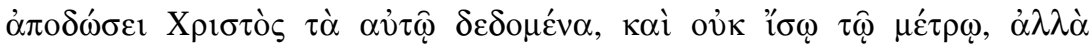

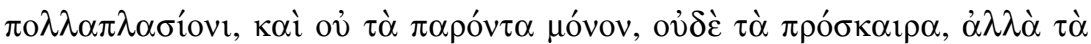

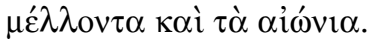

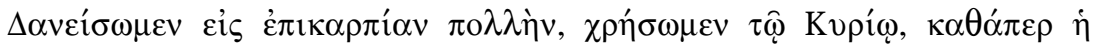

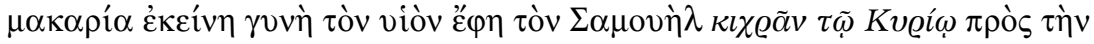

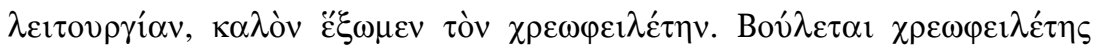

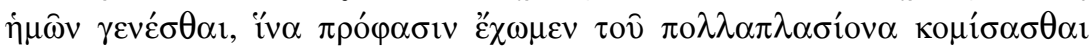

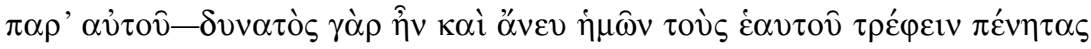

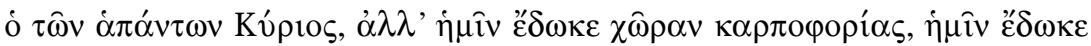

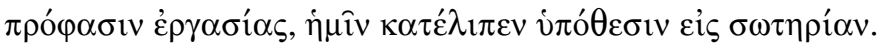

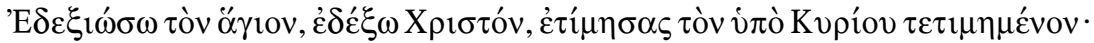

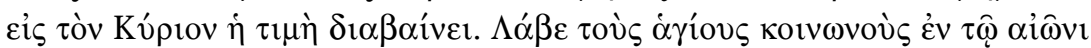

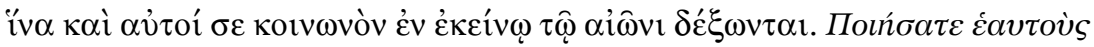

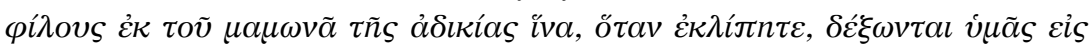

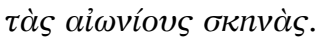

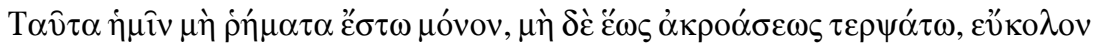

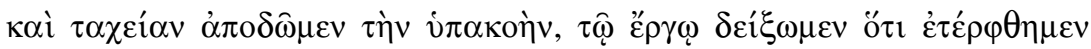

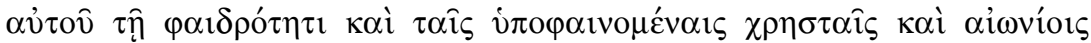

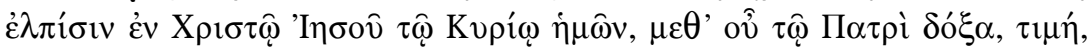

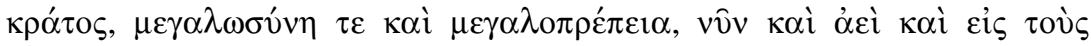
$\alpha i \hat{\omega} v \alpha \varsigma, \alpha \dot{\alpha} \mu \dot{v}$.

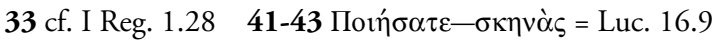

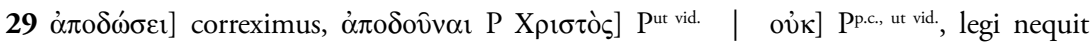

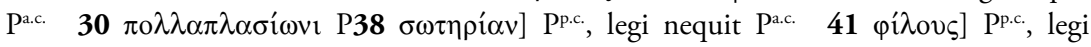

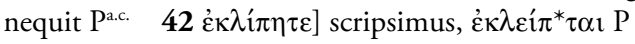

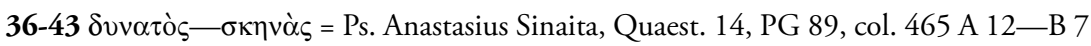

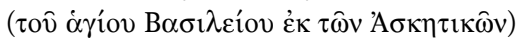


the Lord counts action done to brethren as done to Himself. If you have given to the Lord, how can you not have confidence that you will receive from him? Christ shall give back sufficiently the things given to him, not according to an equal measure but multiplied, and not only in terms of things, nor in terms of transient goods, but [for] the things to come and the things of eternity.

Let us lend for the purpose of a high profit, let us put it to the Lord's use, just as that blessed woman declared her son Samuel loaned to the Lord for service, let us have a debtor who is right. He wishes to become our debtor, in order that we have a reason to acquire a multiplied profit from him. For the Lord of all was able to feed his own poor, even without us, but to us he has given some space for being fruitful, to us he has given a reason for work, leaving us with an occasion for salvation.

You have welcomed the holy, you have received Christ; you have honored who had been honored by the Lord; to the Lord the honor is transferred. Take as partners the saints who are having a share in the world, so that they as well will receive you as sharing in that world. "Make for yourselves friends from the mammon of unrighteousness in order that, when you fail, they may receive you into the eternal dwellings."

Let these be not just words to us; let these not be enjoyable to just listen to. Let us willingly and quickly render back obedience, and demonstrate by our deeds that we have been delighted by his splendour and the appearance of good and eternal hope in Christ Jesus, our Lord, whom with the Father [be] praise, honor, power, majesty, and glory now and ever and to eternity. Amen. 


\section{Commentary}

The reading for the day on which the homily was preached seems to have been (or to have included) Mt 19:16-26 or the parallel version in either Mk 10:17-27 or Lk 18:18-30, ${ }^{17}$ in which Jesus challenges a rich man to sell all that he has in order to follow him. The homilist clearly presumes that the audience is aware of this story as he launches into his topic in the second paragraph of the text.

The homily begins with a call to be a doer of the word and not just a hearer. The audience is reminded of two options for the Christian lifestyle:

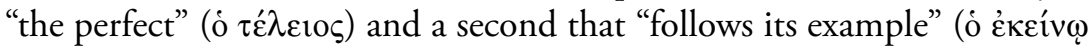
$\pi \alpha \rho \alpha \kappa o \lambda o v \theta \hat{\omega} v)$. Those living according to the second should do all they

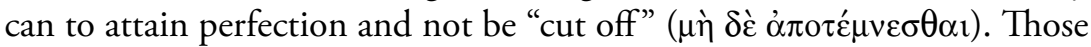
who are perfect know Jesus' teaching to the rich young ruler, advising total divestment as a way to perfection. Such should be practiced daily, the homilist exhorts, "assisting the needy one from his possessions, lest they fail utterly to obey the Savior." ${ }^{18}$ The Lord's self-giving should be the model; the homilist suggests an allusion to Eph 5:2 when he says, "the Lord showed so much love to us so as to give even himself for us."

Anticipating a possible objection from his audience, that total divestment of wealth limits the prospect for stewardship of resources in the future, the homilist argues, "Let no one worry about his stewardship." Literally, the text reads, "Let no one fear about his own housekeeping"

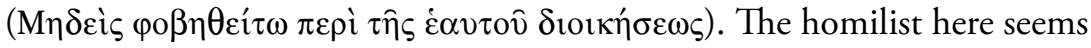
to be suggesting a perceived fear of his audience that giving goods or money to the needy brethren is somehow disrupting the system. His admonition suggests that it is the administration or ordered control of goods that one

17) The Matthew text may be the more likely gospel reading because it alone uses $\tau \dot{\varepsilon} \lambda \varepsilon$ c1o which is the main theme in the first part of the homily. Basil of Caesarea is well known for his dominant use of the first gospel [see, for example, Jean-François Racine, The Text of Matthew in the Writings of Basil of Caesarea (New Testament in the Greek Fathers; Leiden/ Boston: Brill, 2004)], which could perhaps influence those whose works were later attributed to his tradition. If we exclude Matthew, the Lucan text may be the next likely option, since four of the six Gospel citations or allusions to biblical material in this homily are taken from Luke's gospel. Two of those four can be from parallel passages in Mark or Matthew, but the other two are only found in Luke.

18) The text remains ambiguous here on two details: who the assisting possessions belong to (the "perfect" who is helping or the needy who is being helped), and whether it is some power of agency in the possessions themselves or whether it is one of the two human parties who risks failure at obedience. We have deliberately chosen to retain these points of ambiguity in our translation. 
should not worry about. Indeed, the homilist goes on to argue that what you give to God will be repaid: "If you have given to the Lord, how can you not have confidence that you will receive from him?" Thus, there is no reason for a person to fear total divestment of his or her resources in the act of stewardship since God will repay those resources and give that person the ability to be a steward again. ${ }^{19}$

Next, the homilist argues that active love modeled on Christ should be not only fruitful but must frankly make God a debtor, the donor's active love yielding usurious profits from God. Giving one's possessions to the poor is understood more as a transaction between the giver and God than between the giver and the poor person. In fact, the concept of usury is here explicitly not something negative (where it increases one's wealth at the expense of the poor), but positive, much as we find it in some other Christian writers of late antiquity. ${ }^{20}$ God wants to repay us many times

19) The debate over the proper interpretation of Jesus' words to the rich man in Mk 10:21/ Lk 18:22 is found for the first time in Clement of Alexandria, Quis dives salvetur 4-5. If one follows this passage literally, Clement reasoned, then one will violate Jesus' other teaching in Mt 25 to care for the sick, poor and imprisoned. Clement concluded that only a spiritual interpretation of Mk 10:21/Lk 18:22, in which Jesus is understood to demand $\dot{\alpha} \pi \dot{\alpha} \theta \varepsilon 1 \alpha$ towards goods and wealth, is consistent with Jesus' other teaching. While not specifically addressing Mk 10:21/Lk 18:22, other early Christian literature also explored the problem of renunciation versus detachment from wealth. In favor of detachment, cf. Irenaeus' $A H$ IV.30.1-3; Shepherd of Hermas, Parables (or, Similitudes) 1-2; Peter of Alexandria, On Riches 14-15; Gregory of Nazianzus, Or. 14.25; Asterius of Amasea, Hom. 2; John Chrysostom, Homilies on Matthew 77.4; idem, On the Statues II.6; idem, Homilies on 2 Corinthians 19.3-4. In favor of renunciation, cf. Ep. of Barnabas 19; Anonymous Pelagian, On Riches; perhaps also Didache 4.8. Interested readers are further directed to Anthony Meredith, "The Three Cappadocians on Beneficence: A Key to their Audience," in Preacher and Audience: Studies in Early Christian and Byzantine Homiletics, A New History of the Sermon, vol. 1, edited by Mary B. Cunningham and Pauline Allen (Leiden: Brill, 1998), 89-105; John A. McGuckin, "The Vine and the Elm Tree: The Patristic Interpretation of Jesus' Teaching on Wealth", in The Church and Wealth: Papers Read at the 1986 Summer Meeting and the 1987 Winter Meeting of the Ecclesiastical History Society, eds. W. J. Shiels and Diana Wood (Oxford: Blackwell, 1987) 1-14; Howard Clark Kee, "Rich and Poor in the New Testament and Early Christianity," in Through the Eye of a Needle: Judeo-Christian Roots of Social Welfare, eds. Emily A. Hanawalt and Carter Lindberg (Kirksville, MO: Thomas Jefferson University Press, 1994), 29-42; G. E. M. de Ste. Croix, "Early Christian Attitudes to Property and Slavery", in Church, Society and Politics: Papers Read at the Thirteenth Summer Meeting and the Fourteenth Winter Meeting of the Ecclesiastical History Society, Studies in Church History 12 (Oxford: Blackwell, 1975) 1-38.

20) Cf., e.g., Origen, On Psalm 36, Hom. 3.11; John Chrysostom, Homilies on Genesis 41.35; Cassiodorus Explanation of the Psalms, On Psalm 14 and Basil, Hom. 8.6. 
over ( $\pi \mathrm{o} \lambda \lambda \alpha \pi \lambda \alpha \sigma$ íovi; cf. Lk 18:30) what we have "paid" to him when we provide for the needs of the poor. "O poor one, lend to the rich God," Basil exhorts in Hom. 8.6, calling God a "trustworthy guarantor ... for in his generosity, he loves honor." According to De beneficentia, this almsusury transaction is, in fact, "material for salvation." In using the phrase "material for salvation," the homilist seems to suggest that handling material stuff is comparable to ascetic, contemplative prayer, insofar as both relate to salvation.

The image of the alms transaction as a fruitful use of property is also present in other patristic homilies. In a better-known Ps-Basil sermon De misericordia et iudicio ("On Mercy and Justice"), forms of work, either trade or agricultural production serve as common examples in the discussion of justice, along with an exhortation to manual labor: "Do good work with your hands, so that you may have something to give to those in need." ${ }^{21}$ Jacob of Sarug's sixth-century sermon "On the love of the poor" contains an explicit reference to the poor as soil that is fruitful when sown with justice and alms. ${ }^{22}$ Basil points to agricultural profit in a similar manner in his Hom. 6.3, writing, "Imitate the earth, $\mathrm{O}$ man, and let your alms bear fruit... and whatever fruit of beneficence you do yield, you gather up for yourself; for the grace of good works and their reward is returned to the giver." 23

The homilist of De beneficentia next reminds the audience that to receive the holy is to welcome Christ; in honoring the poor, they honor the Lord. Using alms to establish this relationship with others in this life, he says, effects and ensures a receptive communal fellowship in the eternal dwellings. We find this theme in other patristic texts on alms. ${ }^{24}$ For example, in De misericordia et iudicio, the poor ( $\left.\pi \tau \omega \chi \chi^{\circ} \varsigma\right)$ are similiarly identified as "holy" and gifts to them are to be regarded as gifts to Christ. ${ }^{25}$ Repeating

21) C. Paul Schroeder, trans., "On Mercy and Justice," in St. Basil the Great: On Social Justice, Popular Patristics Series 38 (Crestwood, NY: St. Vladimir's Seminary Press, 2009), 106. For the Greek text, see De misericordia et iudicio (CPG 2929), PG 31.1705-1714.

22) Jacob of Sarug, "On the Love of the Poor"; the Syriac text is Homiliae Selectae MarJacobi Sarugensis, vol. 2, ed. Paul Bedjan (Paris, 1906), 816-836, esp. lines 18-22; ET by Sebastian Brock; for selections of Professor Brock's translation and further discussion of Jacob of Sarug's agricultural imagery, see Susan R. Holman, God Knows There's Need: Christian Responses to Poverty (New York: Oxford University Press, 2009), esp. $47 \mathrm{ff}$.

23) Basil of Caesarea, hom. 6.3, trans. M. F. Toal, The Sunday Sermons of the Great Fathers (Chicago: Henry Regnery, 1959), 327.

24) E.g., Shepherd of Hermas Similitude (or, Parable) 2.

25) For Greek see PG 31.1713.1-3. 
the gospel teaching to "make friends by the mammon of unrighteousness," the homilist of De beneficentia concludes the very short sermon as he began: with an order not just to listen but willingly and quickly to put these lessons into action.

\section{Patristic Themes in De Beneficentia}

Early Christian homilies on social concerns might be dated as early as the Shepherd of Hermas and certainly by the time of Clement of Alexandria, but their rapid growth in popularity and numbers seems to begin with the generation after the formal legalization of Christianity, around the middle of the fourth century. The context of social preaching in Greek-speaking late antiquity, particularly as it relates to the Cappadocians and John Chrysostom, has been explored elsewhere at length and will be summarized here only briefly. ${ }^{26}$ While Christians were engaged from the beginning in charitable relief work amongst their Christian and non-Christian neighbors alike, ${ }^{27}$ the imperial legislation of the fourth century influenced

26) See e.g., Pauline Allen, Bronwen Neil, and Wendy Mayer, Preaching Poverty in Late Antiquity: Perceptions and Realities, Arbeiten zur Kirchen- und Theologiegeschichte 28 (Leipzig: Evangelische Verlagsanstaltz, 2009); Susan R. Holman, The Hungry are Dying: Beggars and Bishops in Roman Cappadocia, Studies in Historical Theology (New York: Oxford University Press, 2001); Johan Leemans, Wendy Mayer, Pauline Allen, and Boudewijn Dehandschutter, "Let us die that we may live": Greek homilies on Christian martyrs from Asia Minor, Palestine, and Syria (c. AD 350-AD 450) (London and New York: Routledge, 2003); Wendy Mayer, The homilies of St John Chrysostom, provenance: reshaping the foundations, Orientalia Christiana Analecta 273 (Rome: Pontificium Institutum Orientalium Studiorum, 2005); W. Mayer, "John Chrysostom's use of the Parable of Lazarus and the Rich Man (Luke 16:19-31)", Scrinium. Revue de patrologie, d'hagiographie critique et d'histoire ecclésiastique 4 (2008) 45-59; and W. Mayer, "Poverty and generosity towards the poor in the time of John Chrysostom", in Susan R. Holman (ed.), Wealth and Poverty in Early Church and Society, Holy Cross Studies in Patristic Theology and History 1 (Grand Rapids, MI: Baker Academic, 2008), 140-158.

27) Cf. Justin Martyr, Apology I.67 (PG 6.429; Justin Martyr, Apologies: Introduction, texte critique, traduction, commentaire et index, ed. André Wartelle, Études Augustiniennes, Série antiquité, vol. 117 [Paris: Études Augustiniennes, 1987], 190-192). Cf. Tertullian, Apology 39 (PL 1.470; Tertullian, Opera, Pars I: Opera Catholica, Adversus Marcionem, eds. Eligius Dekkers, Janus G. P. Borleffs and R. Willems, CCSL 1 [Turnhout: Brepols, 1954) 150153]. Cf. Minucius Felix, Octavius (PL 3.260-263 and 335-338; Minucius Felix, Octavius, ed. Michael Pellegrino, CSLP [Turin, Italy: G. B. Paravia and Co., 1972] 11-13, 47-48).

The parallels between Tertullian's Apology and Minucius Felix's Octavius are striking, such that most scholars have concluded that one is dependent on the other, or that both are 
the move into a more organized system of poor relief, usually directed by bishops and other church leaders. ${ }^{28}$ Late antique Christian texts on responses to poverty demonstrate a broad concern for moral issues pertinent to classical philosophy, particularly the cultivation of virtue. Virtue

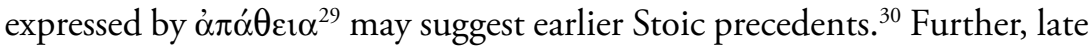
antique Christian texts explicitly connect theology (for example, the issue of Christology) with social ideals. ${ }^{31}$ The poor were popularly identified in the surviving texts as embodiments of Christ, in accordance with Matthew 25. Further, such sermons (especially those of the Cappadocians) sometimes contain language that suggests a view of rich and poor as inherently equal before God. ${ }^{32}$ The expectation of the eschaton demanded a certain

dependent on a third source. A helpful summary of this debate since the early nineteenth century is available in Michael E. Hardwick, Josephus as an Historical Source in Patristic Literature through Eusebius, Brown Judaic Studies 128 (Atlanta, GA: Scholars Press, 1989), 21-22. Examination of the interdependency is also in G. W. Clarke, transl., Marcus Minucius Felix, Octavius, Ancient Christian Writers 39 (Westminster MD: Newman, 1974) 9-10 (supporting the priority of Tertullian).

28) E.g., Codex Theodosianus 16.2.6 (Theodore Mommsen, ed. Theodosiani libri xvi cum constitutionibus sirmondianis, [Bern: Apud Weidmannos, 1905], 836-837; ET: Clyde Pharr, The Theodosian Code and Novels and the Sirmondian Constitutions, The Corpus of Roman Law 1 [Princeton, NJ: Princeton University Press, 1952], 441). Cf. also Peter Brown, Poverty and Leadership in the Later Roman Empire (Hanover, NH: University Press of New England, 2002), 26-32.

29) Cf. Valerie Karras, "Overcoming Greed: An Eastern Christian Perspective," BuddhistChristian Studies 24 (2004): 47-53; Robert Slesinsky, "The Doctrine of Virtue in St. Gregory of Nyssa's 'The Life of Moses," in Prayer and Spirituality in the Early Church, Vol. 1, eds. Pauline Allen, Wendy Mayer, and Lawrence Cross (Brisbane, Australia: Watson Ferguson \& Company, 1998), 341-352.

30) Seneca, De vita beata xxii.4. Cf. Marcia L. Colish, The Stoic Tradition from Antiquity to the Early Middle Ages (Leiden: E. J. Brill, 1990).

31) E.g., Irenaeus, Adversus haereses III.21.9. John Lawson, The Biblical Theology of Saint Irenaeus (London: Epworth Press, 1948), 140; Eric Osborn, Irenaeus of Lyons (Cambridge, UK: Cambridge University Press, 2001), 103. On the relationship of poverty relief rhetoric and Christology, see now Susan R. Holman, "God and the Poor," in Andrew McGowan, Brian Daley, and Timothy Gaden (eds.), God in Early Christian Thought: Essays in Memory of Lloyd G. Patterson, Supplements to Vigiliae Christianae 94 (Leiden: Brill, 2009), 297-321.

32) See, e.g., Susan R. Holman, "The Entitled Poor: Human Rights Language in the Cappadocians." Pro Ecclesia 9 (2000) 476-489; and eadem, "Healing the world with righteousness? The language of social justice in early Christian homilies," in Miriam Frenkel and Yaacov Lev, eds., Charity and Giving in Monotheistic Religions. Studien zur Geschichte und Kultur des islamischen Orients 22 (Berlin/New York: De Gruyter, 2009), 89-110. 
set of responsibilities in the present age. These responsibilities are often associated with a focus on detachment from worldly goods. ${ }^{33}$ Divestment requires a mindfulness of the eschaton, and of a day of divine judgment, ${ }^{34}$ after which God will rule directly over a new heaven and new earth.

Although the terminus post quem and terminus ante quem for De beneficentia spans the late-fourth through ninth centuries, respectively, it shares many of these same concerns in that it expresses by Christian homiletic an explicitly patristic (if pseudonymous) voice for social action. Certain aspects also found in Basil's known genuine sermons also give it a particular Cappadocian "feel," such as the use of the term politeia and the discussion of two lifestyle divestment options. Basil strongly preferred to use language of civic identity and community harmony in his known homilies on moral ethics and charitable divestment, even and usually explicitly within a context based in monastic ideals of simplicity. Whatever its date, De beneficentia seems thus to emerge from a tradition that was deeply rooted in Basil's civic and monastic language and his communal ideals.

In its language about two "ways of life," De beneficentia seems to speak specifically to an ascetic context, or one that addressed monastics as part of the mixed audience. A reference to two (usually contrasting) "ways" is a common topos in Christian texts, ${ }^{35}$ but here the two are not opposites but close and indeed encouraged competitors. Several late antique sermons associated with the Cappadocians contain similar language. For example, the author of the fourth-century homily, De misericordia et iudicio, writes,

\footnotetext{
33) See Brian Matz, "The Principle of Detachment from Private Property in Basil of Caesarea's Homily 6 and Its Context," in Reading Patristic Social Ethics: Issues and Challenges for 21 st Century Christian Social Thought, eds. J. Leemans, B. Matz, and J. Verstraeten, Catholic University of America Studies in Early Christianity (Washington, D.C.: Catholic University of America Press, 2011, 159-182).

34) There are many examples of this; two texts which treat the issue directly are Asterius of Amasea's Hom. 1 and Jerome's Hom. 86, both of which were expositions of Jesus' parable on the rich man and Lazarus (Lk 16:19-31). Cf. Cornelius Datema, ed. Asterius of Amasea, Homilies I-XIV. Text, Introduction and Notes (Leiden: E.J. Brill, 1970), 7-14; Germain Morin, ed., S. Hieronymi presbyteri opera. Pars II: Opera homiletica, Corpus Christianorum Series Latina 78 (Turnhout: Brepols, 1958), 507-516.

35) Cf. e.g., the "two ways" teaching of the Didache, the Epistle of Barnabas, and Irenaeus A.H. V.28.1. One also thinks here of Basil of Caesarea's Homily 21, which argues from Psalm 118:1 that detachment from private property is to be situated within the wider context of one's need for a light burden while traveling the road or way known as the Christian life.
} 


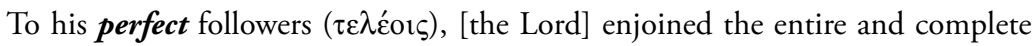
fulfillment of mercy, so that having finished their service to others by means of possessions, they might embark upon service by means of word and spirit. To the rest $\left(\lambda_{0} \pi \pi_{0} \varsigma_{\varsigma}\right)$, he ordained allotment and sharing of what they have, so that in this way they might be seen as imitators of the kindness of God, showing mercy and giving and sharing. ${ }^{36}$

Gregory of Nazianzus also suggests the same option of "perfection" in comparison to a more ordinary perpetual divestment in $O r .14 .18$, where he emphasizes that being wealthy without helping the poor is not a viable Christian option:

No; either we must set everything aside unto Christ that we may become his true followers, taking up the cross, and, unencumbered by anything that would drag us down, buoyantly soar to the world on high and gain Christ at the cost of everything else, ennobled through our humility and through our poverty enriched, or we must share what we have with Christ so that owning possessions may somehow be sanctified in itself by our putting them to good use and sharing them with those who have none. ${ }^{37}$

Basil, too, suggests in Hom. 8.8 that if his audience is unwilling to give everything to the things that are eternal, they ought at least to divide them up so that some are dedicated to one's life in heaven as to a "self-controlled" child, while the rest are used to maintain present prosperity.

All three of these examples, in short, argue that the "perfection" of total divestment is most ideal, but that a second, more gradually divesting alternative is also a legitimate Christian way of life, albeit one fraught with more difficulties for those who might follow this path in their search to attain true "perfection." This is indeed the same general message that the reader finds in De beneficentia.

Two details that are not entirely clear in De beneficentia, however, include, first, the identity of those who are practicing the "second" way of life, and, second, the identity of the poor themselves, although both are identified as "brothers." Given the way these concepts are argued in other known patristic sources, it seems reasonable to suggest that "the perfect" are here understood to be voluntary poor ascetics in the community who

36) Trans. Schroeder, St. Basil the Great: On Social Justice, 107, emphasis added.

37) Gregory of Nazianzus, Or. 14.18, trans. Martha Vinson, St. Gregory of Nazianzus: Select Sermons, Fathers of the Church 107 (Washington D.C.: Catholic University of America Press, 2001), 52, emphasis added. 
live in poverty as part of their ascesis in spiritual perfection. Those living in the second "way" by definition fall short of "perfection." In fact, the homilist suggests, they are at risk of being "cut off" from any hope of perfection unless they daily follow the example of "perfection" through daily divestment that benefits the needy. Nonetheless, by these daily acts of sharing, gifts, or almsgiving, the needy are themselves prevented from "failing to follow the Savior." 38 Such perpetual divestment maintains a synergy that carries all parties into eternity. This idea that the alms or divestment relationship helps not only the donor but also needy persons to get to heaven (which is admittedly suggestive here rather than explicit) is unusual; however, it is repeated again in another sentence near the end of the text. Parallel with the equation of the holy as Christ, honor to the poor being honor to the Lord, the text adds, "Take fellow saints into the age that also the Lord may receive fellowship from them in that age."

While it is impossible to gain any precise measure of the social effect that such prescriptive texts had on their contemporaries at first delivery, what might we conclude about this particular sermon as a voice for social action in its time (whatever that "time" may have been)? Without knowing more about the original context, it is impossible to identify who was meant by the "second" group, those trying for but not quite succeeding at perfection, who seem to be the central focus of the address. We cannot say for certain whether they were monks or laypersons, or whether the sermon was preached in a monastery or parish setting. Nor is it clear if the poor were located inside the monastery, although they were certainly understood here as insiders in terms of church identity. Unlike extant genuine fourth century Cappadocian sermons, this sermon lacks any apparent image of the poor as "other" or outsider. There is no attempt at defending individuals who exist at the fringes of community identity, such as we find in Gregory of Nyssa's two orations on the love of the poor. The poor in De beneficentia are neither Nazianzen's nor Nyssen's uprooted victims of war, nor alienated "lepers" nor repulsive homeless persons; nor are they Basil's community victims, weeping, starving, and in debt. For this very short text, they are simply identified as "the needy" and "the poor," "neighbors" who are at the same time "brethren," "holy" and at risk of losing the path

\footnotetext{
38) This sentence may be most literally translated as, "Let this be practiced, <in accordance with $>$ this precept, every single day by the perfect: not neglecting the one in need but assisting the needy one out of what one has, so that they [which can only mean the needy, the only plural in the sentence] are not completely failing to follow the Savior."
} 
to eternal life. Thus, we suggest, this is clearly an "insider" text, preached to and about those perceived as integral members of the corporate group. Thus, as a call to social action, the homily invites perpetual divestment to the needy as a regular dynamic intended to maintain community life in a balance focused on eternity.

\section{Anonymous Social Homilies Attributed to Basil}

A more substantial understanding of De beneficentia is limited, at present, by the state of scholarship on other pseudo-Basil homilies on social issues that lie, functionally unknown, among the spuria and dubia. It is fairly easy to identify at least the titles and source-texts of the most obvious of these patristic homilies from late antiquity. ${ }^{39}$ Yet despite tools such as $P G$ and the now online TLG that make keyword searches particularly easy, even this promising list may represent only a small proportion of texts that merit further scholarly attention. And the quest to track down a likely text and render it comprehensible remains a gamble; an extended search through these online tools as well as other manuscript catalogues and libraries might yield something relevant to patristic social ethics, or it might not. ${ }^{40}$ While a pseudonymous, spurious, or dubious attribution at

\footnotetext{
39) Most relevant here are BBU, vols. II.1,2 and Georg Graf, Geschichte der christlichen arabischen Literatur, vol. 1, Studi e Testi 118 (Città del Vaticano: Biblioteca Apostolica Vaticana, 1944). Ferdinand Cavallera's 1912 index of Migne's Series Graeca identifies the following examples of suggestive homilies that merit further research in this area: (1) Eusebius of Alexandria (5th c), De caritate (PG 86 ${ }^{1}$.323-328) and De eleemosyna in divitem et Lazarum (PG 86.1.423-452); (2) Ps.-Chrysostom, De jejunio et eleemosyna (PG 48.10591062), De eleemosyna (PG 60.707-712), De eleemosyna (PG 60.747-752), De siccitate (PG 61.723-726, which is now known to be an 11th century homily by Philagathos Cerameo, see discussion in Susan R. Holman, The Hungry are Dying, 84, 86, 88); (3) Nilus (5th c), De voluntaria paupertate (PG 79.967-1060, possibly irrelevant); (4) Theophanes Cerameus (12th c), De divite et Lazaro (PG 132.249-272), De Zacchaeo (PG 132.343-356), and De siccitate (PG 132.1069-1078). The full bibliographic reference to Cavallera's index is: Ferdinandus Cavallera, Patrologiae Cursus Completus, Accurante J.-P. Migne, Series Graeca, Indices (Paris: Fratres Garnier, 1912).

40) For example, Basil's Prologus 7, (De judicio Dei, PG 31.653-676) which is considered genuine Basil (although it does not appear to be listed in the BBU), has a very promising title, and is available in the TLG, does not on a superficial read appear to relate to social welfare issues, or at best they seem very thin on the ground. The eager scholar is constantly challenged by the question of whether to spend more time with such a text or move on to others that are more obviously promising.
} 
least suggests a terminus post quem, unknown authorship or attestation in a single manuscript creates further uncertainties. As we found in our work on De beneficentia, responsible research on such texts can demand extensive, collaborative multidisciplinary skills, the ability to search imaginatively, flexibly, and carefully for possible connecting hints and themes, not a little patience, and a large portion of caution about any final attribution of author or date. Perhaps such studies call for a new methodology that is less dependent on traditionally standard base referents such as authorship, building on more obvious factors (for example, phrasing, multilingual parallels, and less explicit connectors across the social history of antiquity) that might draw on new applications of digital resources.

Our limited understanding of De beneficentia is helped by the current status of research on Basil's texts (particularly Fedwick's BBU) and the now-extensive research on patristic responses to poverty. Those who wish to build on this present strength to further explore pseudonymous or spurious texts related to Basil and patristic social action might begin with Fedwick's BBU, vol. II.1-2, particularly Fedwick's identification of eight other pseudo-Basil homilies that also concern issues of poverty, wealth, and social justice. These are summarized briefly below. ${ }^{41}$

\section{De misericordia et iudicio ${ }^{42}$}

Perhaps the best known Ps.-Basil sermon on social issues is the anonymous fourth-century sermon De misericordia et iudicio, "On mercy and justice." Greek manuscripts attribute it to Basil but Coptic manuscripts attribute authorship to one of three other fourth-century Greek bishops. ${ }^{43}$ As noted above, this text is now available in two English translations. It is this sermon that immediately follows De beneficentia in the Berlin manuscript.

\footnotetext{
41) The brief summary of these eight sermons is intended as at best a very introductory aid to researchers and does not necessarily reflect the latest state of scholarship on each particular text.

42) De misericordia et iudicio (CPG 2929), PG 31.1705-1714, trans. Sister M. Monica Wagner, Saint Basil: Ascetical Works (New York: Fathers of the Church, 1950), 507-512. For commentary, see BBU, vol. 2.2, pp. 1189-1190. The Greek word кpío1s as it is used throughout this text appears to denote interchangeably either "justice" or "judgement." 43) Athanasius, archbishop of Rakote; Epiphanius of Salamis; and Athanasius of Alexandria (BBU, vol. II,2, 1189-1190).
} 


\section{De Diuite et Lazaro paupere et de paenitentia}

Attested only in Arabic, Fedwick’s $\$$ Arab. 2, "De Diuite et paupere Lazaro, et de paenitentia," a sermon on the rich man and Lazarus the poor man, is "assigned for the seventh Friday of Lent" and is present in fourteen extant manuscripts. ${ }^{44}$ Georg Graf also listed this homily in his Geschichte der christlichen arabischen Literatur in $1944,{ }^{45}$ and in 1970 Joseph-Marie Sauget provided a more extensive description, including the first and last few lines in Arabic with a Latin translation: ${ }^{46}$

[inc:] Desidero proponere, auditoribus qui aperiunt aures-suas ad-audientes libros qui <proveniunt $>$ a Spiritu Sancto, sermonem utilem ... ${ }^{47}$

[des:] Et-nunc, o fratres, cum cognovistis quod hoc <est> veritas et-non futilitas, oremus Dominum-nostrum et-Deum-nostrum Iesum Christum ut det nobis auxilium ad prosequendum beneplacitum-eius et oboedientiam-ei, cui laus etgloria in saeculum saeculorum. Amen. Amen. Amen.

Even without a ready translation of the full text from the Arabic, this sermon's context is particularly interesting in light of the company it keeps in the homiliary Sauget describes. There it is number 36 in a group of eight sermons (hom. 33-40) ${ }^{48}$ within the homiliary that are either sermons on the story of the Good Samaritan (hom. 33, 34, 35, 40) or on the story of Lazarus and the rich man (hom. 36-39), sermons attributed either to Basil (hom. 36), John Chrysostom (hom. 33, 37), a certain Theodulus (hom. 34), Jacob of Sarug (hom. 38), or anonymous (hom. 35, 39, 40). This group of eight, in other words, explicitly relate to the topic of charity or neighborly compassion for the needy; all of them are placed shortly before those in the homiliary that are (also in a group) clearly about Easter; thus we may reasonably conclude that these eight were intended as Lenten sermons. A

44) Fedwick’s $¥$ Arab. 2, listed and described at BBU, vol. II.2, 1211.

45) Graf, Geschichte der christlichen arabischen Literatur, 322, lines 26-33 (incomplete).

46) Joseph-Marie Sauget, "L'homéliaire arabe de la Bibliothèque Ambrosienne (X. 198 Sup.) et ses membra disiecta," Analecta Bollandiana 88 (1970) 391-474, at 445. The hyphens that connect some of the Latin words are part of Sauget's translation, presumably to add precision in indicating the associated Arabic words or phrases.

47) Fedwick (BBU, vol. II.2, 1211) translates this into French as, "Ecoutez-moi, je suis là pour ceux qui écoutent, qui ouvrent leurs oreilles à l'écoute du livre qui vient de l'esprit saint."

48) That is, homily 36 is Ambrosianus X. 198 Sup., fol. 169-175 (Sauget, "L'homéliaire arabe," 418). 
translation of not only the ps.-Basil text but perhaps all eight of these Arabic patristic sermons would be most welcome.

\section{3. "On Penance, Mercy, and Alms"}

Fedwick identifies a sermon, on penance, mercy, and alms, ${ }^{49}$ among Basil's spuria et alia. This sermon, too, exists only in Arabic and in only one manuscript. ${ }^{50}$

\section{De eleemosyna et precatione (CPG 2982)}

Another sermon, on mercy and begging, available only in Armenian (Fedwick's $\ddagger$ Arm. 6) is found in eight manuscripts. ${ }^{51}$ The incipit has been translated into Latin as, "Praecognoui autem a me ad uos factum consolationis consilium de beneficentia."

\section{De eleemosyna et in-eleemosyna}

Another sermon available only in Armenian (Fedwick’s $¥$ Arm. 7$)^{52}$ is listed without any information about available manuscripts. Fedwick notes only that the incipit can be translated, "Ne quis puerilibus et indiscretis cogitationibus audeat," and that it is sometimes attributed to Yovhannēs Mandakuni.

\section{6. "Admonition on Riches"}

This Slavic sermon (Fedwick’s $¥$ Slav. 12$)^{53}$ is extant in over a dozen manuscripts. The incipit in some may be translated "With wealth have you overgrown" or in others as "From great wealth are you boastful."

\footnotetext{
49) Fedwick's $¥$ Arab. 9 (BBU, vol. II.2, 1213; Graf, Geschichte der christlichen arabischen Literatur, vol. 2, Studi e Testi 133 (Vatican City: Biblioteca Apostolica Vaticana, 1947), 491.

50) h3363 in Fedwick (BBU, vol. II.1, 332), i.e., Biblioteca Apostolica Vaticana Barberiano or. 41 , ff. $330 \mathrm{r}-340 \mathrm{v}$.

51) BBU, vol. II.2, 1217.

52) BBU, vol. II.2, 1217.

53) BBU, vol. II.2, 1258.
} 


\section{7. "On Riches"}

The full title of Fedwick’s $\neq$ Slav. 55 is, "On riches, when someone becomes rich and from his riches refuses to give alms to the poor." 54 The incipit may be translated, "If you can do good, do not refuse."

\section{8. "Against the Rich"}

The full title of Fedwick’s $¥$ Slav. 211 is "Sermon against the rich and those who do not give alms to the destitute and poor." 55 It exists in a single manuscript; the incipit may be translated, "Why are you grieving, man, unwilling to give what is perishable to the destitute and poor." The title may suggest an obvious parallel with Basil's genuine sermon, Homilia in divites. ${ }^{56}$

These eight examples cited in Fedwick are, of course, only a small selection of what may be perhaps the most obvious of ps.-Basil sermons on social welfare topics. Others may still lie hidden, as yet unrecognized, under general or misleading titles. Fedwick points, for example, to the many other "undetermined works" he identifies as "terra incognita."

\section{Conclusion}

Against this broad background of text, translation, social context, and the yet-unfathomed sea of spuria and dubia on patristic responses to poverty, what might we conclude about De beneficentia as it relates to late antique texts on social action? Given that virtually nothing is certain about its original context, a best answer ultimately depends (at least in part) on where it belongs between the fourth and ninth centuries. Several features, noted above, are unlike extant genuine fourth century Cappadocian sermons. The narrative, for example, lacks any apparent image of the poor as "other" or outsider. That is, there is no attempt at defending individuals who exist at the fringes of community identity. The poor here are simply identified as "the needy" and "the poor," "neighbors" who are at the same

\footnotetext{
54) BBU, vol. II.2, 1264-1265.

55) BBU, vol. II.2, 1283.

56) Basil, Homilia in divites (also commonly known as hom. 7). Ed. and trans. Yves Courtonne, Saint Basile: Homélies sur la richesse: Édition critique et exégétique (Paris: FirminDidot, 1935), 39-71; ET ("To the rich) in Schroeder, St. Basil the Great: On Social Justice, 41-58.

57) BBU, vol. II.2, 1294-1295.
} 
time "brethren," "holy" and at risk of losing the path to eternal life. These generic characterisitics do not suggest a specific date, but do suggest an "insider" text, preached to those perceived as part of the larger, corporate group or monastic community.

Yet although the text is considered spurious and therefore often judged to be "late" (however one defines "late"), its language is not unlike Basil's acknowledged sermons. Indeed, the presence of ninth and twelfth century citations argue for a Byzantine use of an earlier text that was assumed to be Basil's but, perhaps due to the vagaries of time, became so rare as to create this resulting uncertainty. If, contrary to our cautious readings, De beneficentia were genuinely by Basil of Caesarea - and this is admittedly an enormous "if"- then its apparent, central, reference point of monastic "perfection," which is not present in his better-known "poverty sermons," 58 could suggest it belonged to a similar setting as that of Basil's Asceticon, given the evident intra-monastic focus of the content as we have it, ${ }^{59}$ that is, it was originally delivered to and within a monastic church setting in the presence of an audience that might include non-monastic individuals or those whose social roles connected both monastery and village (or local civic community). Until further information is available to suggest otherwise, however, we suggest that De beneficentia might most prudently continue to be regarded as pseudonymous, perhaps preached in a village setting where the region's monks followed Basil's Rule and drew heavily on his recognized sermons.

Regardless of date or author, however, there is no question that De beneficentia is a deliberate call for social action, whether or not such action ever took shape. Such imagined action is defined by, or at least assumes a central monastic identity for the primary speaker and his view of the ideal relationship to the needy poor. This monastic basis is speaking into a broader community; it seems to assume lay or secular persons in the audience whose lives are deliberately modeled on monastic ideals at some lesser level, yet engaged in a practice of committed, regular divestment. Finally, the homily assumes an interdependent salvation dynamic that calls for the social action of perpetual divestment to the needy as a regular activity maintaining community life in a balance focused on eternity. These features of this text should be kept in mind in any discussion of applying such a narrative to modern Christian social ethics.

\footnotetext{
58) Hom. 6, 7, 8, and the hom. On Ps. 14b, as discussed in Holman (2001).

59) For more on this text and context, see Anna Silvas, The Asketicon of St. Basil the Great (New York: Oxford University Press, 2005).
} 